\title{
Doce Diálogo: música e relações de gênero em duas canções de Chico Buarque
}

\author{
Letícia Grala Dias ${ }^{1}$ \\ Maria Ignez Cruz Mello ${ }^{2}$ \\ Acácio Tadeu Camargo Piedade ${ }^{3}$
}

\begin{abstract}
RESUMO: A partir da comparação entre duas canções de Chico Buarque, "Cotidiano" e "Sem Açúcar", constata-se um diálogo de música e letra entre as duas canções, fortemente marcado pelas relações de gênero. Nesta comunicação buscamos identificar, tanto no âmbito da letra quanto no discurso musical, as representações das relações de gênero estabelecidas pelas duas canções.
\end{abstract}

PALAVRAS-CHAVE: relações de gênero, canções de Chico Buarque

\section{Relações de gênero e Música}

A questão das relações de gênero no campo musical, conforme salientou a pesquisadora Maria Ignez Mello, é ainda muito incipiente no Brasil, sendo que pesquisas a respeito dessa temática têm sido mais desenvolvidas em países como os EUA e Inglaterra (Gomes e Mello, 2007). Partindo-se do pressuposto de que a música conta com códigos de significação social (McClary, 1993), acreditamos que ela é afetada por essas determinações "seja reproduzindo, afirmando ou contestando modelos e costumes vigentes" (Gomes e Mello, 2007, p. 393). Nessa mesma direção, Mello afirma que "o sistema das relações de gênero está ligado às atribuições sociais de papéis, poder e prestígio, sendo sustentado por ampla rede de metáforas e práticas culturais associadas ao masculino ou ao feminino" (2007). Na música ocidental pode-se encontrar como esse sistema afeta as estruturas musicais, por exemplo no fato de que desde muito tempo são usadas designações e conceitos atrelados a questões de gênero. A idéia de "forma-sonata", por exemplo, apresenta geralmente o primeiro tema como sendo "masculino", enérgico, rítmico, objetivo, enquanto o segundo tema é "feminino", mais melódico, lírico, flutuante (McClary, 1993). Em um estudo sobre a terceira sinfonia de Brahms, McClary aponta que:

\footnotetext{
${ }^{1}$ Acadêmica do curso de Licenciatura em Música CEART/UDESC e Bolsista de Iniciação Científica PROBIC/ UDESC.

${ }^{2}$ Orientadora e professora do Departamento de Música CEART/UDESC.

${ }^{3}$ Orientadora e professora do Departamento de Música CEART/UDESC.
} 
essa designação dos temas como "masculino" e "feminino" foi muito comum na pedagogia e crítica dos anos 60, apesar da recente musicologia tentar negar esse tipo de categorização e afirmar que na verdade isso não tinha qualquer significado. Contudo, eliminar a terminologia não apaga as questões de gênero existentes na estrutura musical desse período: visto que muitos dos temas de sonata em questão inspiram-se na semiótica da "masculinidade" e "feminilidade", assim como na ópera e nos poemas sinfônicos, eles são facilmente reconhecidos nas narrativas musicais (op.cit., p. $332)^{4}$.

A autora mostra como análises de sonatas clássicas e românticas remetem a essas designações:

o motivo de abertura é alto, enfatizado por um conjunto de metais e sopros, empurrado aparentemente por um esforço hercúleo para um ponto lançamento dentro da narrativa do primeiro movimento. Sua sonoridade, volume, agressão, o marcam semioticamente como "masculino" (op.cit., p. 335).

Neste sentido, pesquisas de autores como McClary (1991), Kramer (1990) e Citron (1993) trazem discussões acerca da reprodução do modelo da masculinidade no código musical (Dias e Mello, 2007). Frente a essa reprodução majoritariamente masculina, as representações da subjetividade feminina na música também constituem foco de pesquisas como as de McClary (1991), Walterman (1993), Citron (1993), Cusick (1994).

Estudos no Brasil que abordem a questão das relações de gênero no campo musical podem ser encontrados em Bastos (1999), Mello (2005) e Piedade (2004). Estas pesquisas, através de uma perspectiva antropológica, abordam essa temática em aldeias indígenas brasileiras. Também no heavy metal, Walser (1993) destaca a questão das relações de gênero neste meio musical que se mostra majoritariamente masculino. Diniz (1984), Kater (2001) e Holanda (2006), trazem à luz trabalhos de compositoras, que mesmo influenciando o cenário musical de sua época, não obtiveram grande reconhecimento. Joana Hollanda ainda aponta quão pequena é a inserção de obras de compositoras tanto na programação de concertos como na literatura especializada, no caso brasileiro.

Nas últimas décadas, áreas como a musicologia e a antropologia têm apontado "novos caminhos para se pensar tanto o trajeto feminino ao longo das transformações e da

\footnotetext{
${ }^{4}$ Tradução do inglês feita pelo colega de pesquisa Rodrigo Cantos.
} 
consolidação de várias narrativas que permeiam a Música Ocidental, quanto as implicações que as relações de gênero têm sobre a política e a produção musical mundial" (MELLO, 2007).

\section{As canções e o compositor}

\section{I - O compositor}

Chico de Holanda de aqui e de alhures

“[...] Inventado porque necessário, vital, sem o qual o Brasil seria mais pobre, estaria mais vazio, sem semana, sem tijolo, sem desenho, sem construção".

Rui Guerra (1998)

Como bem observou Chaves (2004), as canções de Chico Buarque caracterizam a música popular brasileira, estabelecendo uma estreita intimidade entre a melodia e a letra, além de apresentarem aguda consciência social. Outra característica presente na obra de Chico Buarque são canções que tematizam a mulher, dando-lhe voz. É considerado um dos compositores que melhor exprime os sentimentos femininos em poesia e em música. E o mais curioso é que o faz através de uma perspectiva feminina. Para Adélia Bezerra, autora do livro Figuras do feminino na canção de Chico Buarque (BEZERRA, 2001) diz que "é sempre no contexto de uma intensa relação afetiva que se desvenda o fundamental da mulher, a abordagem das canções de temática feminina inevitavelmente deslizará para o terreno dos afetos, obrigando-nos a descortinar o poderoso veio da lírica amorosa do autor" (BEZERRA, 2003) $)^{5}$ Afirma que na obra de Chico aparecem figuras de mulheres amadurecidas na luta e na paixão (como "Bárbara" e Joana de "A Gota d'água"), mulheres fortes (como a protagonista de "Com açúcar, com afeto"), a mulher órfica, que continua sambando após a quarta-feira de cinzas (como em "Ela desatinou" e "Madalena"), a mulher prometéica (como a protagonista de "Logo eu" e "Cotidiano"), aquela "que encerra seu homem num abraço de ferro de um quotidianismo insuportável, metafórico e literal ("me aperta pra eu quase sufocar"), além da tragicidade de "Angélica", a favelada do morro de "Meu Guri", e muitas outras mulheres, que representam a maternidade ferida, antiheroínas,

${ }^{5}$ Em entrevista para a revista Cult em maio de 2003. Disponível em http://www.chicobuarque.com.br-chicoartigos. 
prostitutas, etc. O discurso feminino também ganha voz nas canções de Chico em canções como "O meu amor"'.

A seguir, serão comentadas duas canções de Chico Buarque: Cotidiano e Sem Açúcar. A escolha dessas canções se deu devido à constatação de uma relação entre ambas as canções marcada fortemente por metáforas de gênero, questão que se faz central nessa comunicação e da qual falaremos mais adiante.

\section{II - As canções}

\section{I - Cotidiano}

Composta em 1971, a canção de Chico Buarque traz a narrativa de um monótono e enfadonho dia-a-dia de um casal, como podemos observar logo nos primeiros versos da canção: Todo dia ela faz tudo sempre igual / me sacode às seis horas da manhã / me sorri um sorriso pontual / e me beija com a boca de hortelã. Essa idéia de monotonia também é traduzida pela melodia desses versos, uma melodia repetitiva e pulsação enfática ${ }^{7}$ :
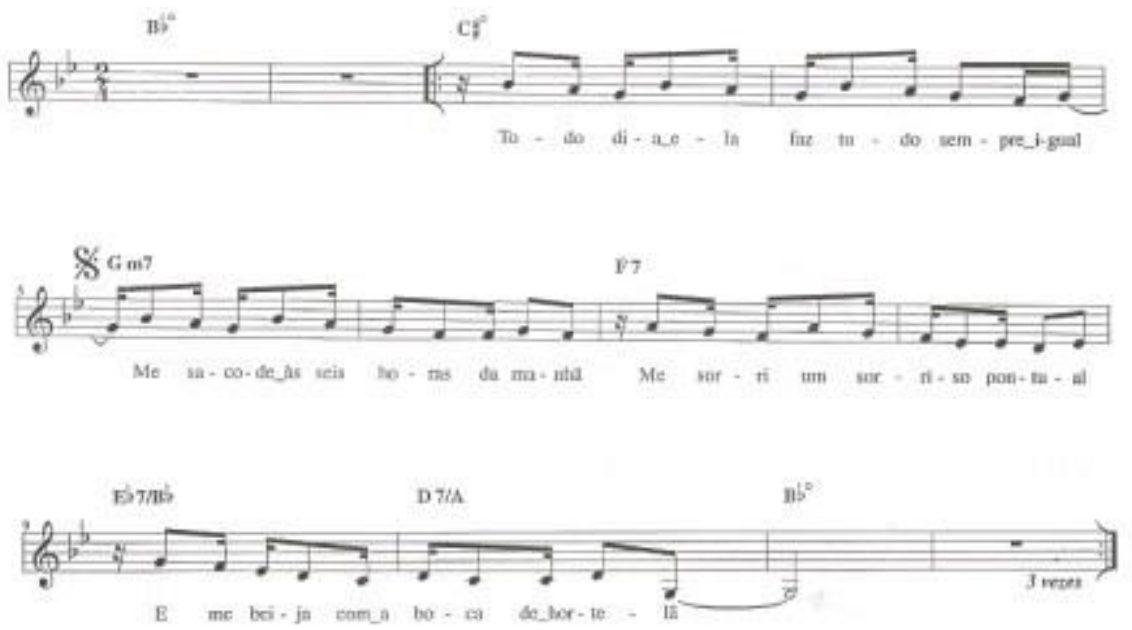

\footnotetext{
${ }^{6}$ Disponível em www.chicobuarque.com.br .

${ }^{7}$ Essa "pulsação enfática" pode ser claramente sentida e observada em um vídeo de uma apresentação de Chico Buarque disponível no youtube (http://br.youtube.com/watch?v=WBwo5MzB7io) onde o próprio Chico marca o pulso com um instrumento de percussão enquanto canta.
} 
Note-se que a repetição das notas sib, lá e sol acontece ciclicamente, numa repetição que "estonteia" acentuando assim o clima de monotonia desejado. A frase Todo dia ela faz tudo sempre igual encerra, de forma sucinta, a temática dessa canção, ou seja, remete à idéia de uma rotina entediante, um vai e volta, um dia-a-dia desgastado ao qual a canção se refere.

Os versos: me sorri um sorriso pontual / [...] todo dia ela diz que é pra eu me cuidar / [...] seis da tarde como era de se esperar [...] evidenciam a repetição que sempre acontece. O ritual diário é também mostrado por sabores como hortelã / café / feijão, ligados ao ciclo do dia noite-janta/manhã/dia-almoço.

A nota sol (tônica, pois a canção apresenta-se sob a tonalidade de Sol menor) aparece em duas oitavas abrangendo regiões de tessituras distintas. A melodia desce de $\mathrm{si}^{\mathrm{b}} \mathrm{a}$ sol, uma tessitura de uma décima, formando uma escala menor natural. Desse modo, sol, usada no final de cada conjunto de frases, confere uma sensação de conclusão à música, ou como se diz popularmente, um "chão".

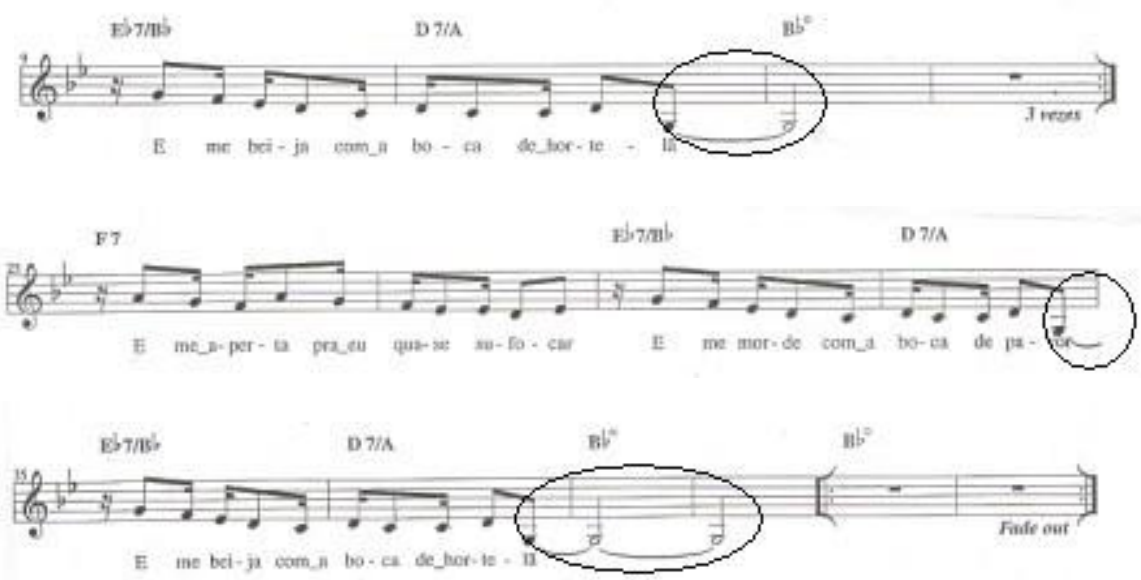

De forma muito original e pouco comum na MPB, o acorde inicial é um acorde diminuto. Este acorde tem uma posição especial na música, ocupando o lugar de tônica, no início e nas conclusões das estrofes da seção A. A presença deste acorde nestes pontos capitais da canção confere um sinal de instabilidade (ou "infelicidade" da cadência) que faz retornar o ciclo do cotidiano. Este acorde, na forma como é usado aqui, sem dúvida é 
altamente representacional da infelicidade e revolta no discurso masculino, o fracasso no acoplamento de uma tônica, ainda que menor.

Após uma exaustiva repetição da seção A, aparece uma seção B de 12 compassos que termina em ré dominante:

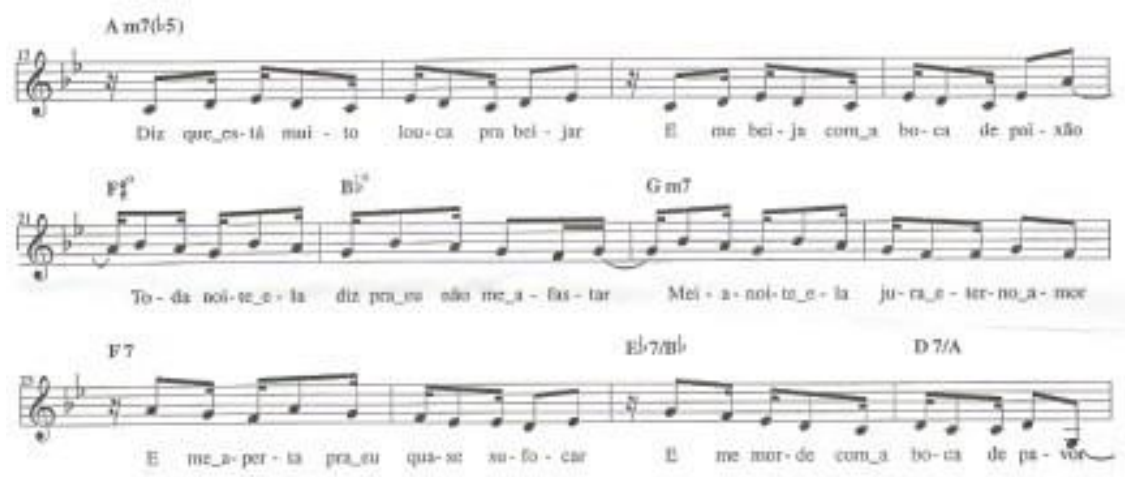

Para então novamente voltar à seção A, anunciando que o novo dia será igual: todo dia ela faz tudo sempre igual...

Curioso notar a progressão harmônica um tanto modal que Chico usa nesta canção:

$$
i-\mathrm{VII}-\mathrm{VI}-\mathrm{V}
$$

Este padrão harmônico, muito comum no pop e rock, mas pouco usual na música de Chico Buarque, revela mais uma tentativa de expressar o caráter cíclico e monótono de um cotidiano sufocante. O modalismo é sem dúvida uma referência nesta peça. Que poderia expressar essa relevância do modo eóleo aqui? A junção deste padrão harmônico-melódico modal pode remeter a representações do antigo, ou ainda, à distância de um passado guerreiro masculino, éthos do homem que chega em casa após a batalha e precisa de sua mulher doce e submissa. 


\section{II - Sem Açúcar}

Sem Açúcar apresenta uma curiosa vinculação com Cotidiano. A introdução instrumental da canção é uma citação ${ }^{8}$ da melodia de Cotidiano:

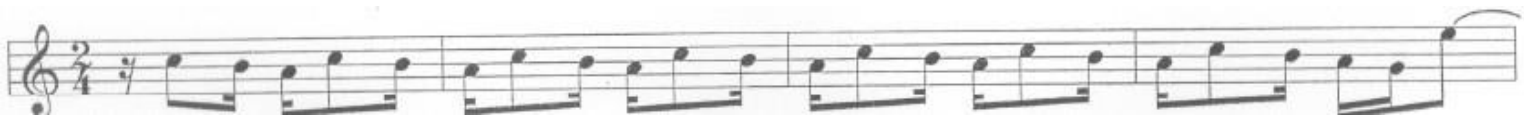

A melodia desses compassos é tocada por uma flauta transversal. Após a introdução, a melodia passa a ser cantada (no caso da versão analisada, a interpretação é de Maria Bethânia), na tonalidade de Lá menor. Logo no terceiro compasso dessa seção inicial, justamente sobre a sílaba tônica da palavra "diferente", a harmonia utilizada traz uma cor "diferente" à tonalidade, através do uso de um acorde sobre o segundo grau alterado $(H)$, adentrando a região da Napolitana ${ }^{9}$ (acorde de $\mathrm{B}^{\mathrm{b}}$ na tonalidade de $\mathrm{Am}$ ):

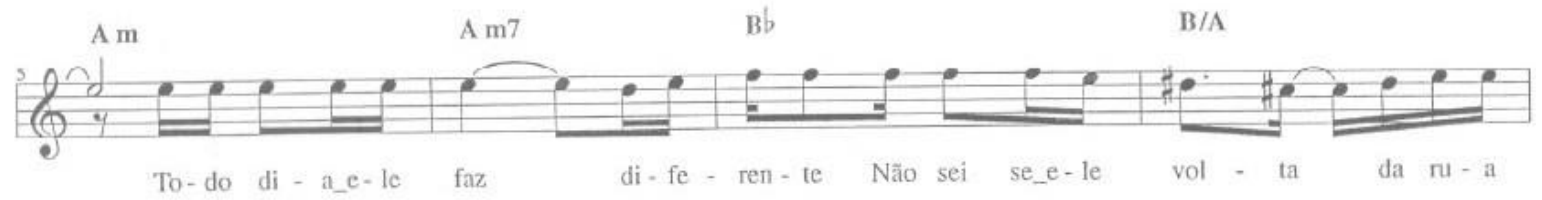

O uso desse acorde, logo no início da canção, traz uma grande novidade na paleta harmônica, sendo que se estabelece uma relação de correspondência entre a frase inicial da letra da música, "todo dia ele faz diferente", e o encadeamento harmônico. A novidade, entretanto, segue com o próximo acorde, $\mathrm{B} / \mathrm{A}\left(\mathrm{V}_{3}^{4}\right)$, uma dominante de $\mathrm{V}$ com o baixo que volta à nota lá, fundamental da tonalidade da música. Na gravação, por várias vezes o baixista mantém o lá no segundo acorde, formando um trecho pedal onde uma tríade sobre por semitom. Tudo isso aponta para o "diferente", o masculino conforme a visão feminina da personagem cantante. Finalmente, a resolução ocorre em $\mathrm{V}^{6}(\mathrm{E} / \mathrm{G} \#)$.

A canção apresenta-se sob a tonalidade de Lá menor com a seguinte seqüência harmônica: (o que com finalidade puramente didática, chamaremos aqui de sequiência 1)

\footnotetext{
${ }^{8}$ Essa melodia apresenta-se um tom acima em relação a sua versão em Cotidiano (que está em Gm). Sem Açúcar apresenta-se na tonalidade de Lá menor.
} 


\begin{tabular}{|l|l|l|l|}
\hline $\mathrm{Am}$ & $\mathrm{Am} / \mathrm{G}$ & $\mathrm{F} 7$ & $\mathrm{E} 7 / 4$ \\
\hline $\mathrm{AM}$ & $\mathrm{Am} 7$ & $\mathrm{Bb}$ & $\mathrm{B} / \mathrm{A}$ \\
\hline
\end{tabular}

No início da canção a progressão Am - Am/G - F7 - E 74 acompanha a melodia da introdução seguida da progressão $\mathrm{Am}-\mathrm{Am} 7-\mathrm{Bb}-\mathrm{B} / \mathrm{A}$ que acompanha os primeiros compassos da canção após a introdução.

Contudo, observamos uma tonicização ${ }^{10} \mathrm{em}$ Lá Maior (sequiência 2), evidenciado pelo encadeamento harmônico utilizado entre os compassos 9 a 19; 27 a 37 e 45 a 55:

\begin{tabular}{|c|c|c|c|c|c|}
\hline E/G\# & Em6/G & F\# & F\#/E & B7/D\# & G\#m7(b5) \\
\hline F\#m7 & F\#m/E & $\mathrm{E} / \mathrm{D}$ & & C\#m7 & F\#7(b13) \\
\hline Dm7 & & G7(13) & & $\mathrm{A} / \mathrm{E}$ & \\
\hline
\end{tabular}

Assim, temos um “jogo” entre Lá menor e Lá Maior na canção. No final da música esse jogo se encerra e após a seqüência 1, em vez de seguir-se a seqüência 2 (Lá Maior), segue-se novamente o encadeamento de acordes de Lá menor (seqüência 1).

Um interlúdio instrumental também aparece intercalado na canção, sempre em seguida ao aparecimento da sequiência 2 (tonicização em Lá Maior) e apresenta o mesmo tema da introdução instrumental :

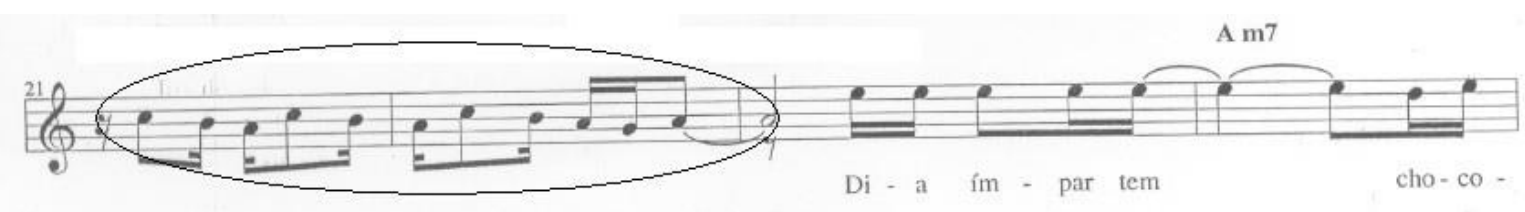

A incerteza é um sentimento que perpassa a narrativa dessa canção evidenciado pelo uso das expressões "não sei se", "talvez", "quem sabe", como mostram estes versos:

${ }^{10}$ É observado também o uso das notas das notas fá\#, dó \# e sol\# na melodia em alguns compassos da seqüência 2. 
Todo dia ele faz diferente / não sei se ele volta da rua / não sei se me traz um presente / não sei se ele fica na sua / talvez ele chegue sentido / quem sabe me cobre de beijos [...]; assim também como a insatisfação: ou nem me desmancha o vestido / ou nem me advinha os desejos [...] / enquanto ele dorme pesado / eu rolo sozinha na esteira. Essa incerteza da personagem feminina é também expressada pela ambigüidade tonal e modulações, pela alternância maior/menor, ou seja, pelo jogo entre Lá maior e Lá menor que perpassa a canção.

\section{Paralelo entre as canções: $o$ igual e o diferente}

Constatamos uma relação dialógica entre essas canções. A citação de Cotidiano tanto na introdução e o aparecimento intercalado dessa citação na música (interlúdio instrumental) confere um particular diálogo entre as duas canções. Essa "conversa" entre Sem Açúcar e Cotidiano está repleta de metáforas de gênero tanto em seu discurso semântico quanto musical. Vamos refletir sobre esse diálogo.

Em Cotidiano, quem fala, quem nos conta a narrativa, é um homem, e através do discurso masculino (descontente) nessa canção que nos é revelada uma figura feminina. É “ele” falando "dela”. Já em Sem Açúcar, a voz está com a mulher, e é sob a ótica feminina (angustiada) que a narrativa é contada. É “ela" falando "dele”.

Na primeira canção, o discurso musical é mais objetivo, enfático, como podemos observar na melodia da canção. Na segunda, a narrativa é contada por meio de uma melodia bem mais variada, mais estendida. Os prolongamentos silábicos (Tatit, 1994) reforçam esse caráter.

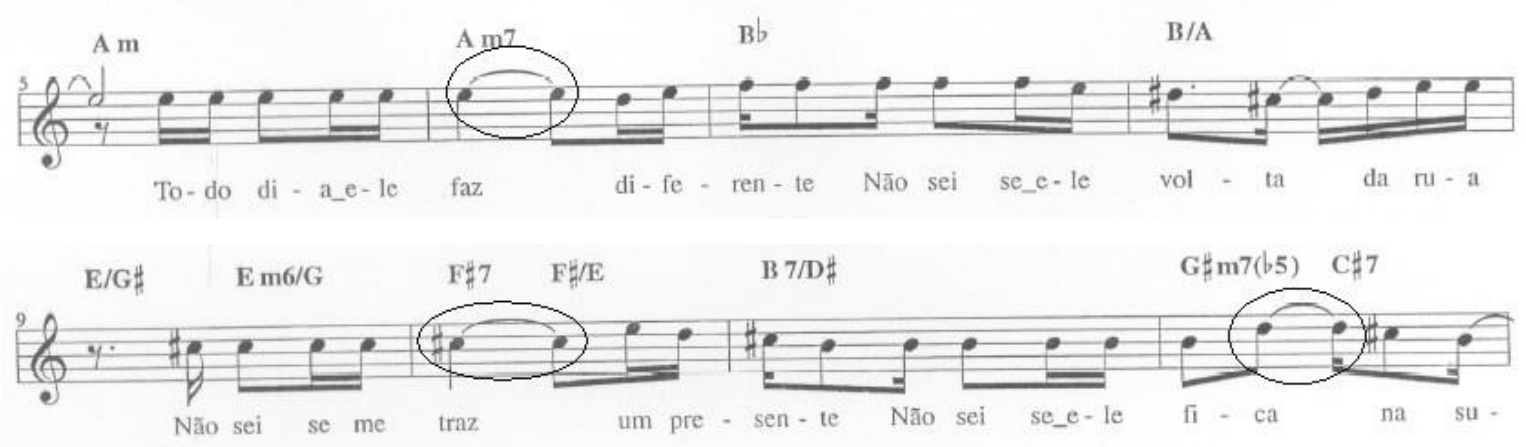




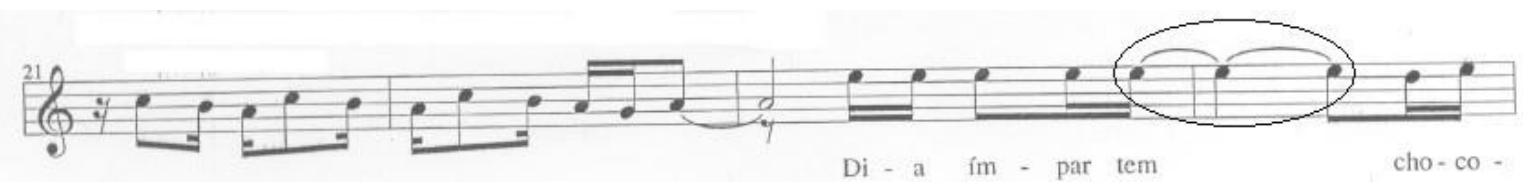

Em Cotidiano, a pulsação e o ritmo são mais "marcados". As notas longas aparecem somente em fim de frases, sendo que as figuras mais usadas são colcheias e semicolcheias. Já em Sem Açúcar, a sensação da pulsação não é tão evidente e há maior uso de notas prolongadas (com ligaduras) no curso da frase musical.As características musicais dessas canções conferem uma conotação particular a cada uma, o que aqui atribuímos ao masculino e feminino ${ }^{11}$.

Logo no início da letra das duas canções constatamos frases antagônicas, mas que se complementam: ele diz "todo dia ela faz tudo sempre igual", e ela diz "todo dia ele faz diferente". Assim, evidenciam-se os pares ele/ela e igual/diferente. As canções, vistas em conjunto, parecem mostrar como é forte a diferença de gênero, aliada a representações musicais (melodia repetitiva/desenvolvida, harmonia modal/modulante) e expressões de afetos (reclamação/dúvidas, marido descontente/mulher angustiada). O ponto em comum é o desequilíbrio, a insatisfação, a busca de exprimir, cada qual conforme sua visão de mundo, a impossibilidade da real felicidade do casal. O casal, aqui, são as duas canções elas mesmas.

\footnotetext{
${ }^{11}$ Evidenciamos aqui que há distinções construídas socialmente que são atribuídas ao masculino e ao feminino, contudo, não conferimos a um ou a outro qualquer tipo de juízo de valor.
} 


\section{As canções}

\section{I - Letras}

Canção: Cotidiano (1971)

Autor: Chico Buarque

LP: Construção
Canção: Sem Açúcar (1975)

Autor: Chico Buarque

LP: Chico Buarque e Maria Bethânia ao Vivo
Todo dia ela faz tudo sempre igual

Me sacode às seis horas da manhã

Me sorri um sorriso pontual

E me beija com a boca de hortelã

Todo dia ela diz que é pra eu me cuidar

E essas coisas que diz toda mulher

Diz que está me esperando pro jantar

E me beija com a boca de café

Todo dia eu só penso em poder parar

Meio dia eu só penso em dizer não

Depois penso na vida pra levar

E me calo com a boca de feijão

Seis da tarde como era de se esperar

Ela pega e me espera no portão

Diz que está muito louca pra beijar

E me beija com a boca de paixão

Toda noite ela diz pra eu não me afastar

Meia-noite ela jura eterno amor

E me aperta pra eu quase sufocar

E me morde com a boca de pavor

Todo dia ela faz tudo sempre igual

Me sacode às seis horas da manhã

Me sorri um sorriso pontual

E me beija com a boca de hortelã.
Todo dia ele faz diferente

Não sei se ele volta da rua

Não sei se me traz um presente

Não sei se ele fica na sua

Talvez ele chegue sentido

Quem sabe me cobre de beijos

Ou nem me desmancha o vestido

Ou nem me adivinha os desejos

Dia ímpar tem chocolate

Dia par eu vivo de brisa

Dia útil ele me bate

Dia santo ele me alisa

Longe dele eu tremo de amor

Na presença dele me calo

$\mathrm{Eu}$ de dia sou sua flor

Eu de noite sou seu cavalo

A cerveja dele é sagrada

A vontade dele é a mais justa

A minha paixão é piada

Sua risada me assusta

Sua boca é um cadeado

E meu corpo é uma fogueira

Enquanto ele dorme pesado

Eu rolo sozinha na esteira 


\section{II - Partituras \\ COTIDIANO}
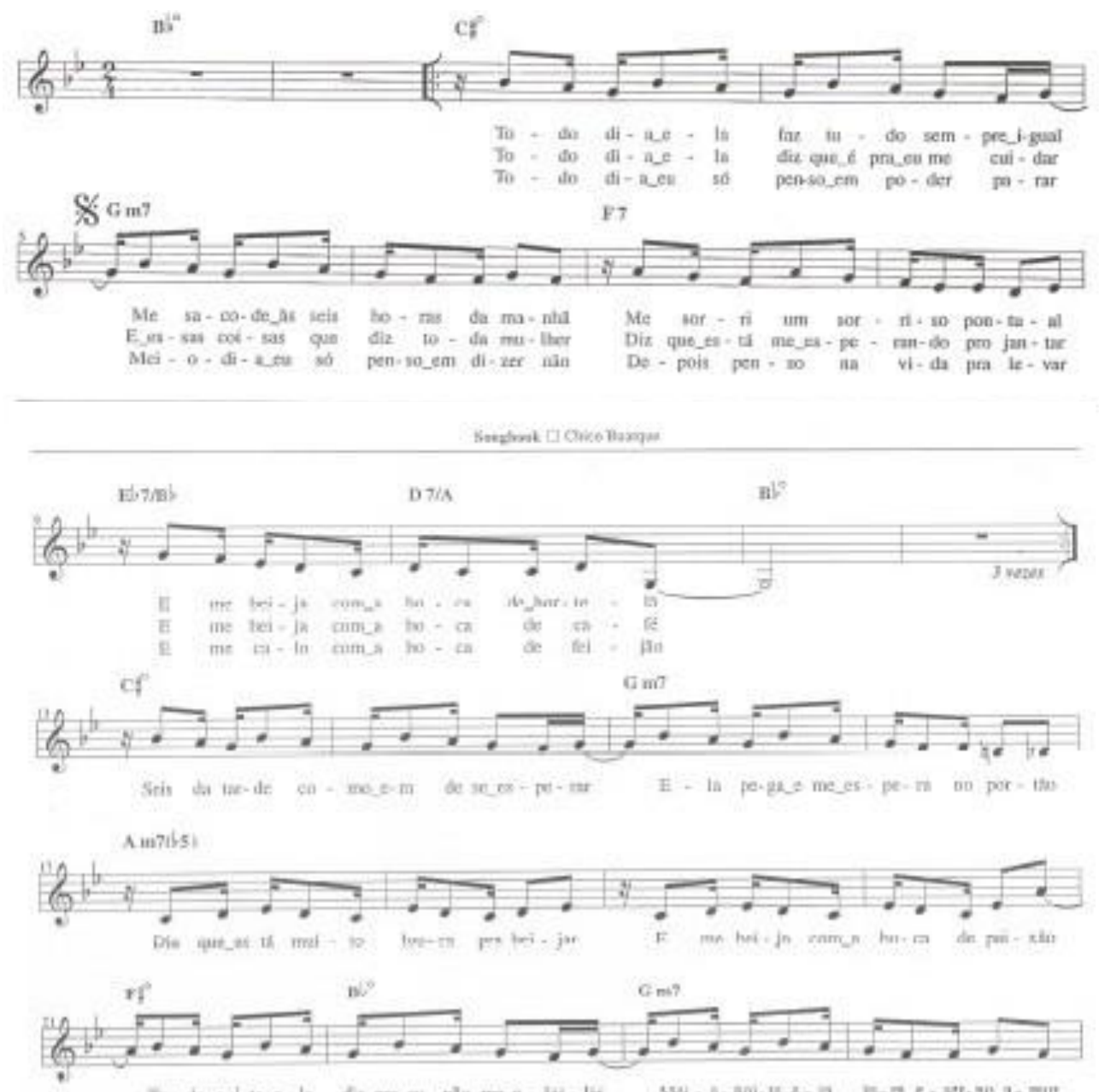

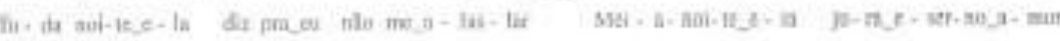
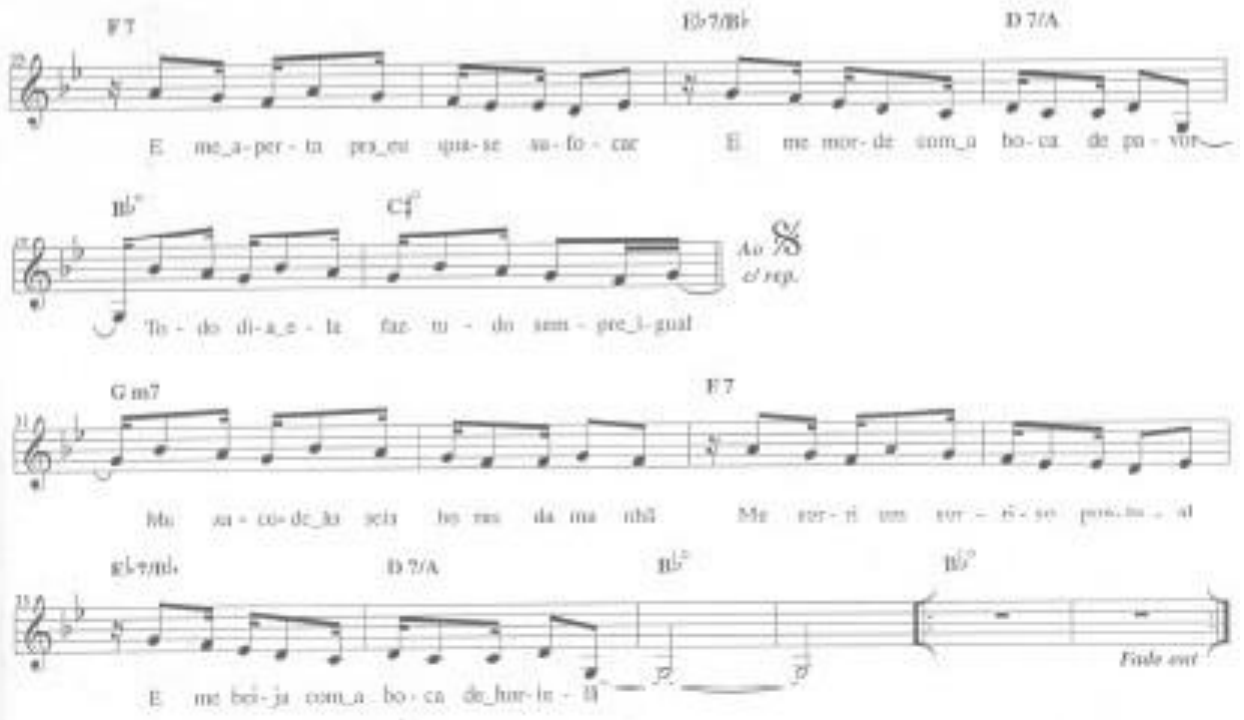

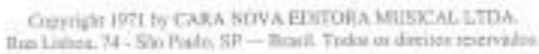

DAPesquisa, Florianópolis, v.3 n.5, p.719-734, 2008. 


\section{SEM AÇÚCAR}

\begin{tabular}{|c|c|c|c|}
\hline \multicolumn{4}{|c|}{ Sergheak D Chios thaye } \\
\hline $\mathbf{A} \mathrm{m}$ & $A \mathrm{~m} / \mathrm{C}$ & FT & $\left.\mathrm{E}_{4}\right]$ \\
\hline
\end{tabular}
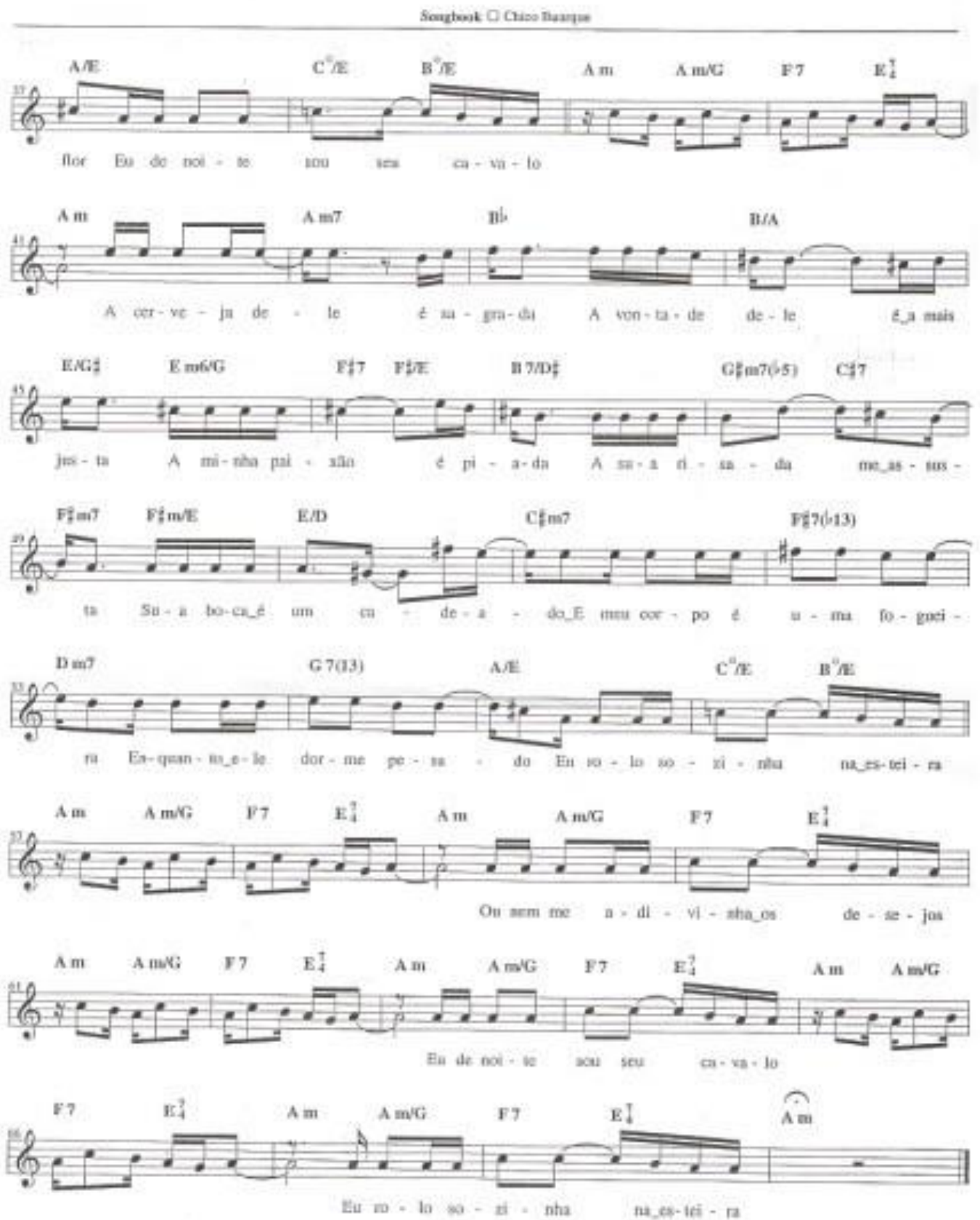

Cepprigte HTS by CAHA NOVA ERTONA MUESCAL LTDA

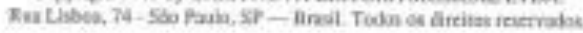




\section{Considerações finais}

Constatamos uma relação dialógica entre as canções Cotidiano (1971) e Sem Açúcar (1975), ambas de Chico Buarque, e que este diálogo está repleto de metáforas de relações de gênero. Na primeira, temos a narrativa de um homem que fala de uma mulher e de seu cotidiano de casal; na segunda canção, é ela quem vai falar de um homem e expressar sua insatisfação.

Pudemos observar que o discurso de cada um é particularmente distinto e, no caso dessas duas canções, o código musical também traduz essa diferença. Mesmo referindo-se às vezes ao mesmo sentimento (insatisfação, por exemplo), a forma de expressá-lo aparecerá muito diferente entre eles.

Ambas as canções possuem estreita ligação entre música e letra. Em Cotidiano e em Sem Açúcar, a melodia é portadora do texto, ou seja, a melodia "diz" o mesmo que diz o texto. Destacamos também a presença de um discurso masculino e feminino nas canções traduzido também musicalmente.

Procuramos analisar aqui, ainda que brevemente, a maneira como foi representada a fala (discurso) 'dela' e 'dele' tanto em seu aspecto discursivo semântico quanto musical. Ou seja, evidenciar as distinções dos discursos feminino e masculino presentes nessas duas canções, não olhando apenas para o quê falam ou de quem falam, mas também a maneira como cada um irá representar e expressar seus sentimentos e opiniões em sua fala e como o código musical nos conta.

Dentre as várias "faces" de Chico Buarque, destacamos aqui o fato de ele ser um dos compositores da MPB que melhor exprime os sentimentos femininos e os expressa em música e poesia.

Enfim, podemos dizer também que essas canções provêm de uma aguda observação da realidade, de uma agudeza crítica sobre a realidade social (Chaves, 2004) e que as representações de gênero aqui verificadas ultrapassam o que poderia ser mera reprodução de estereótipos banalizados ou "naturalizados" pelo senso comum. Ao contrário disso, é a visão de alguém que está atento à realidade social, às relações de poder presentes na sociedade e também atento às particularidades e subjetividades de cada um. 


\section{Bibliografia:}

CHAVES, Celso Loureiro. Chico Buarque das canções. ZERO HORA, 2004. Disponível em: http://www.chicobuarque.com.br-chico-artigos.

BASTOS, Rafael de Menezes. A musicológica Kamayurá: para umaantropologia da comunicação no Alto Xingu. $2^{\text {a }}$ Ed. da UFSC, 1999.

CHEDIAK, Almir. Songbook Chico Buarque. Rio de Janeiro, 1990.

CITRON, M. J. Gender and the Musical Canon. Cambridge: University Press, 1993.

CUSICK, S. G. "Feminist Theory, Music Theory, and the Mind/Body Problem".

Perspectives of New Music, Vol 32, Number 1 (Winter 1994).

DIAS, Letícia G.; MELLO, Maria. I. C. Do Folclore a World Musica: trajetória de dois grupos femininos em Florianópolis. In: IV SIMPÓSIO DE PESQUISA EM MÚSICA. 2007. Curitiba, DeArtes, 2007. v. 4. p. 379-386.

DINIZ, E. Chiquinha Gonzaga: uma história de vida. Rio de Janeiro: Rosa dos Tempos, 1984.

GOMES, Rodrigo Cantos Savelli; MELLO, Maria Ignez Cruz. Relações de gênero e rock'n'roll: um estudo sobre bandas femininas de Florianópolis. In: $3^{\circ}$ Prêmio Construindo a Igualdade de Gênero - Redações e artigos científicos vencedores - 2008. Brasília: Presidência da República. Secretaria Especial de Políticas para as Mulheres, 2008. Disponível em:

<http://www.cnpq.br/premios/2007/construindo_igualdade/pdf/3_premiacao.pdf>. HOLANDA, J.C. Eunice Katunda (1915-1990) e Esther Scliar (1926-1978): Trajetórias individuais e análise de sonata para piano 'Sonata de Louvação' (1960) e 'Sonata para Piano’ (1961). Tese de Doutorado em Música do PPGM/UFRGS, 2006.

HOLLANDA, Chico Buarque. Cotidiano. In.: Construção. Disco. Rio de Janeiro, 1971. 1975. . Sem Açúcar. In.: Chico Buarque e Maria Bethânia ao vivo. Rio deJaneiro,

KATER, Carlos. Eunice Katunda, Musicista Brasileira. São Paulo: Annablume, 2001.

KRAMER, L.. Music as Culural Practice, 1800-1900. California: University of California Press: 1990.

MCCLARY, Susan. Narratives Agendas in "Absolute" Music: Identity and Difference in Brahms's Third Symphony. In: Musicolology and Difference: gender and sexuality in music scholarship. SOLIE, Ruth A. (orgs), University of Califórnia Press, 1993, p. 326344.

MCCLARY, Susan. Gender and Barque Music. I COLÓQUIO DE MÚSICA ANTIGA DE MINAS GERAIS. Belo Horizonte, UFMG, 2007. (cadernos ainda não publicados oficialmente).

MELLO, M. I. C. Relações de Gênero e Musicologia: Reflexões para uma Análise do Contexto Brasileiro. In: Simpósio de pesquisa em música 3, 2006, Curitiba. Anais do Simpósio de pesquisa em música 3. Curitiba : DeArtes UFPR, 2006. p. 69-74. 
MELLO, Maria Ignez Cruz. Relações de gênero e musicologia: reflexões para uma análise do contexto brasileiro. Revista Eletrônica de Musicologia, XI, Setembro de 2007. Disponível em: <http://www.rem.ufpr.br/REMv11/14/14-mello-genero.html>.

PIEDADE, Acácio Tadeu de C. O canto do Kawoká: música, cosmologia e filosofia entre os Wauja do Alto Xingu. 2004. 254p. Tese (Doutorado) Programa de Pós-Graduação em Antropologia Social. Universidade do Federal de Santa Catarina, 2004.

TATIT, Luiz. Semiótica da canção. São Paulo: Editora Escuta, 1994.

WALSER, Robert. Running with the Devil : power, gender, and madness in heavy metal music. Middletown: Wesleyan University Press, 1993.

www.chicobuarque.com.br 